\title{
The Sarcheshmeh thickened tailings scheme - a case study
}

\author{
A Roshdieh ATC Williams Pty Ltd, Australia \\ P Williams ATC Williams Pty Ltd, Australia \\ KD Seddon ATC Williams Pty Ltd, Australia
}

\begin{abstract}
This paper presents a case study on the design, construction, commissioning and early operations of a major upgrade of the tailings storage facilities at Sarcheshmeh mine, Iran.

The Sarcheshmeh mine is located in a semi-arid environment with average annual rainfall of $260 \mathrm{~mm} /$ year and evaporation of 2,800 $\mathrm{mm} /$ year. Make-up water supply comes from an alluvial borefield.

The mine commenced operations around 1980. By 2000, the original tailings storage was full. Short-term measures to increase capacity were recognised as being both unsafe and unsustainable. In addition, the existing tailings and water management practices were inadequate for a proposed expansion.

An initial options study was undertaken with the principal objectives of:

- Improving water utilisation.

- Providing storage for an additional $900 \mathrm{Mt}$ of tailings at a production rate of $33 \mathrm{Mtpa}$.
\end{abstract}

The recommended option was installation of paste thickeners together with down-valley discharge of the paste and thickened tailings. A full feasibility study and design followed.

This paper will cover the following components of the project:

- Tailings properties.

- Thickener selection.

- Beach slope evaluation.

- The water management system.

In this design $12 \times 24 \mathrm{~m}$ paste thickeners were utilised, which is currently the largest installation of paste thickeners for copper. The underflow solid concentration was planned to be around $60 \%$ solids to achieve a maximum beach slope of $1.75 \%$.

Construction of the improvements to the system has been completed and the upgraded tailings management system is in its early years of operation with satisfactory outcomes. In this article, the various components of the system are described and outcomes are discussed.

\section{$1 \quad$ Introduction}

Sarcheshmeh, which means the 'origin of the spring' in Persian, is the oldest of the National Iranian Copper Industries Company ( $\mathrm{NIClCO}$ ) copper mines in Iran. It is located in Kerman province in southern central Iran at an elevation of $2,700 \mathrm{~m}$. It is a world-class ore body. The mine is an open-cut operation on the northern side of a small mountain range at the head of the Shur River Valley. The ore is crushed in-pit before conveying a distance of $1.5 \mathrm{~km}$ to the concentrator at an elevation of approximately $2,550 \mathrm{~m}$.

Production commenced in the early 1980s at a rate of only 2 Mtpa, but significant increases have occurred since. The current (2014) production rate is 60,000 t/day (22 Mtpa) scheduled to soon increase to 
$90,000 \mathrm{t} /$ day (33 Mtpa). The existing tailings management scheme was deemed not to be appropriate for the increased throughput. The original tailings deposition scheme comprised of tailings dewatering in conventional thickeners to around $40-45 \%$ solids by weight at the concentrator. The slurry then flowed in a concrete gravity flume for some $15-20 \mathrm{~km}$ to an impoundment downstream of the mine on the Shur River (the main embankment).

The initial impoundment was created by the construction of a $70 \mathrm{~m}$ high embankment. By around the year 2000 the impoundment was full. Hence, a scoping study commenced in 2002. After extensive evaluation of alternatives, the decision was taken to improve the water recovery by utilisation of paste thickeners on the underflow from the existing conventional thickeners, and also by improving the efficiency of the existing tailings decant recovery system.

To provide ongoing tailings storage (for phase 2 at $33 \mathrm{Mtpa}$ ) it was also necessary to raise the existing dam and the opportunity was taken to minimise the height of the raise by employing down-valley discharge of paste and thickened tailings (Williams 2000). As a further water savings measure, a water storage dam was recommended (Shur River Dam). An overall plan of the tailings deposition scheme together with the mine site is shown in Figure 1.

The overall net present cost of the upgrade of the tailings disposal scheme at year 2004 was estimated at approximately USD $200 \mathrm{M}$ in net present value (NPV) terms. The construction of various components of the system started from 2005 with the last part completed in 2013. The actual construction cost has been approximately USD $140 \mathrm{M}$.

\section{$2 \quad$ Project overview}

The final system upgrade included the following major components which are presented in Figure 1:

- A gravity feed pipeline to the paste thickeners.

- $12 \times 24 \mathrm{~m}$ diameter paste thickeners.

- Down-valley thickened discharge from immediately below the thickener location.

- Raising of the existing embankment.

- An $84 \mathrm{~m}$ high water storage dam on the Shur River, upstream of the tailings storage, and adjacent to the thickeners.

- A water return system from the thickeners, the Shur River Dam, and from the decant pond at the main embankment. 


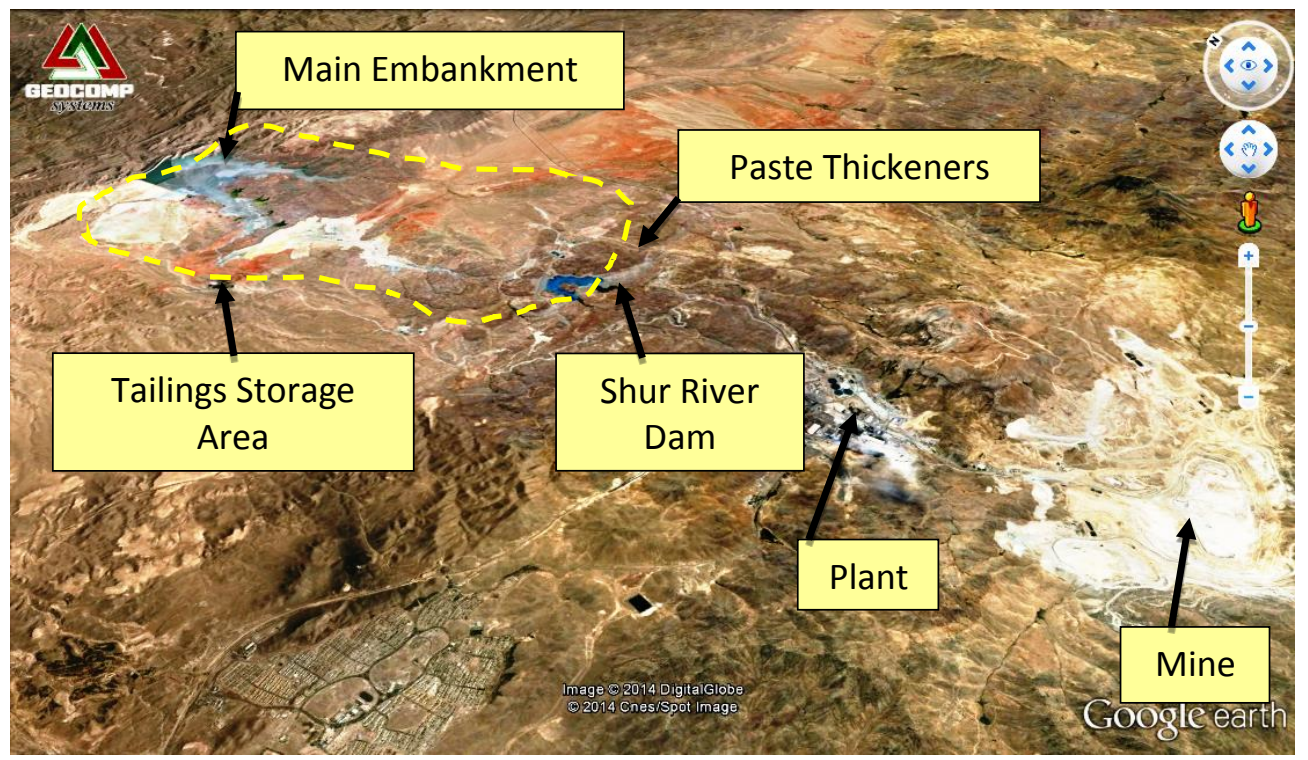

Figure 1 Overall mine and tailings dam layout

\section{$3 \quad$ Tailings properties and climate conditions}

Sarcheshmeh tailings have been tested at different stages of the project; the tailings particle-size distribution from a number of different tests is shown in Figure 2.

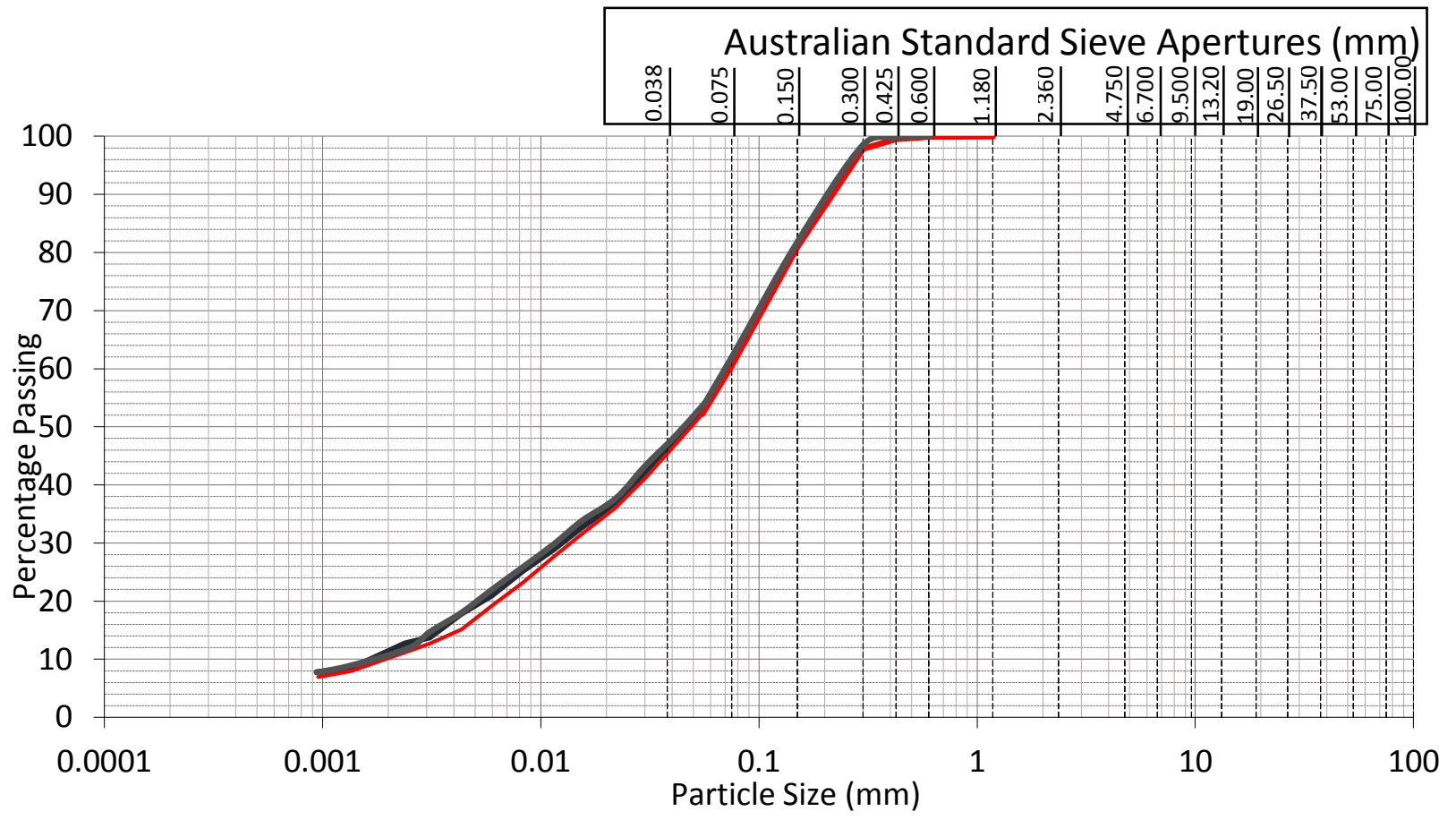

Figure 2 Tailings particle-size distribution

The typical Atterberg limits are tabulated below, giving the tailings a unified soil classification (USC) classification of sandy clay (CL).

- PL: 17.

- LL: 27.

- PI: 10. 
The tailings have a soil particle density (SG) of 2.80. Also, tailings yield stress and plastic viscosity versus tailings solids concentrations are shown in Figures 3 and 4 respectively.

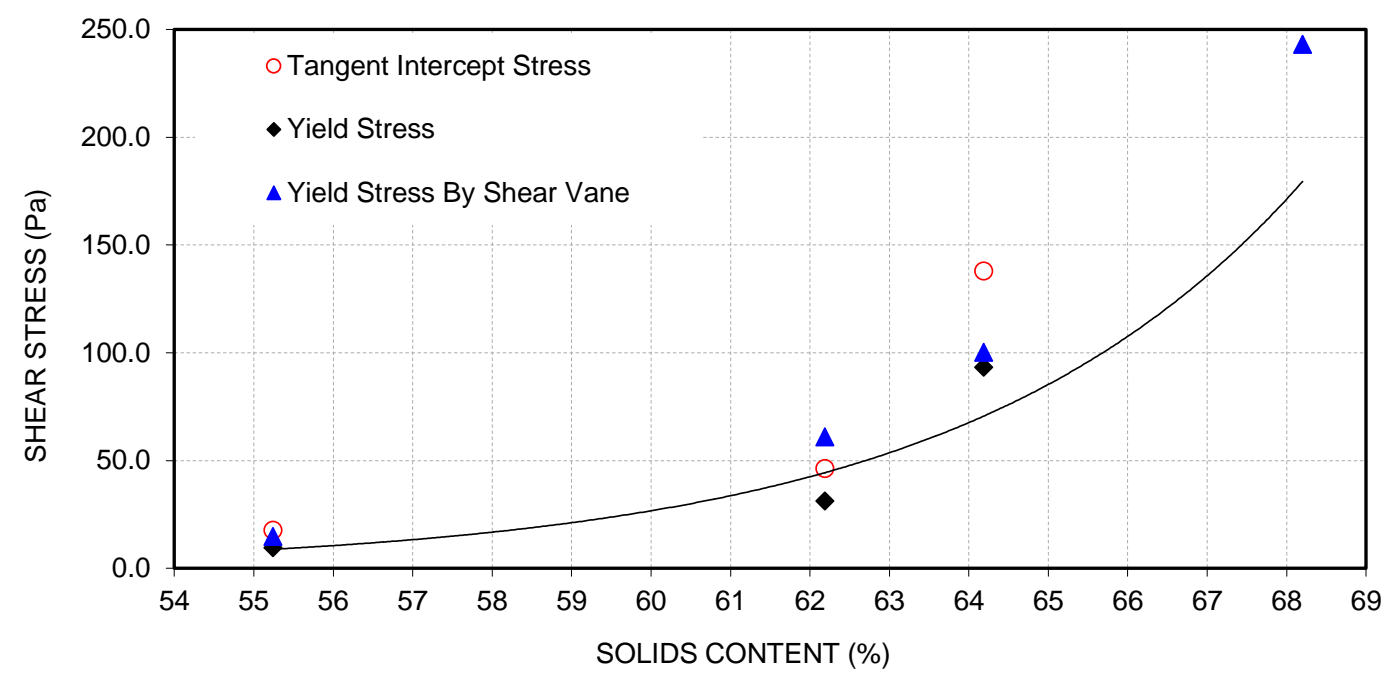

Figure 3 Tailings yield stress versus solids concentration

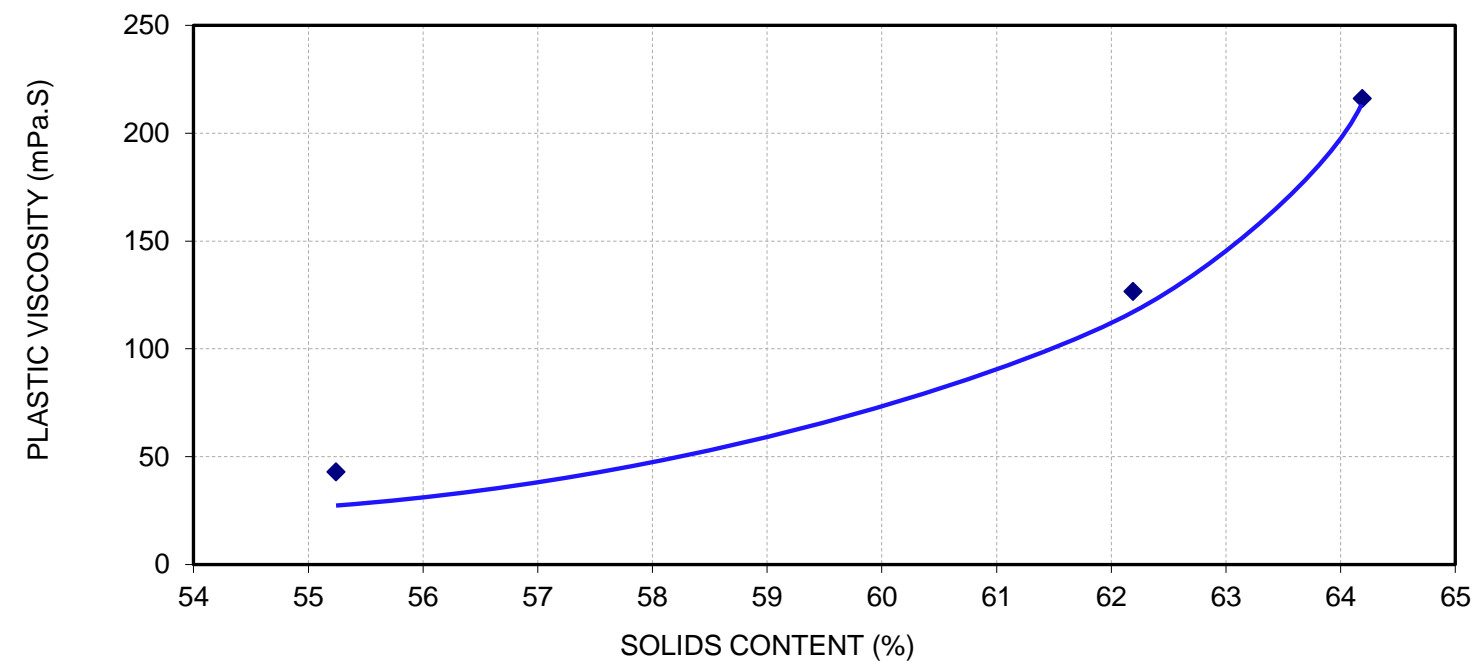

Figure 4 Tailings plastic viscosity versus solids concentration

Sarcheshmeh mine is located in a semi-arid environment with average annual rainfall of $260 \mathrm{~mm} / \mathrm{y}$ (at the concentrator site) and evaporation $2,800 \mathrm{~mm} / \mathrm{y}$. Most of the rainfall occurs in winter, falling as snow at higher elevations. The quantity of rainfall is strongly dependent on elevation, being much lower further down the valley to the north.

\section{$4 \quad$ Thickener selection}

As part of the design, the decision was made to utilise paste thickeners prior to the discharge of tailings, to increase the solids concentration at the deposition point. This results in higher water conservation and also steeper beach slopes. The latter led to savings in embankment construction costs. Locating the thickeners close to the head of the tailings storage required pump back of decant water to the plant, but importantly avoided the need to pump thickened tailings.

The paste thickener plant involves twelve paste thickener units, each with a diameter of $24 \mathrm{~m}$, which were supplied by Dorr-Oliver Eimco (now FLSmidth) (MacNamara et al. 2011), the largest such installation in the world at the present time. Figure 5 shows the paste thickener plant nearing the end of construction. 


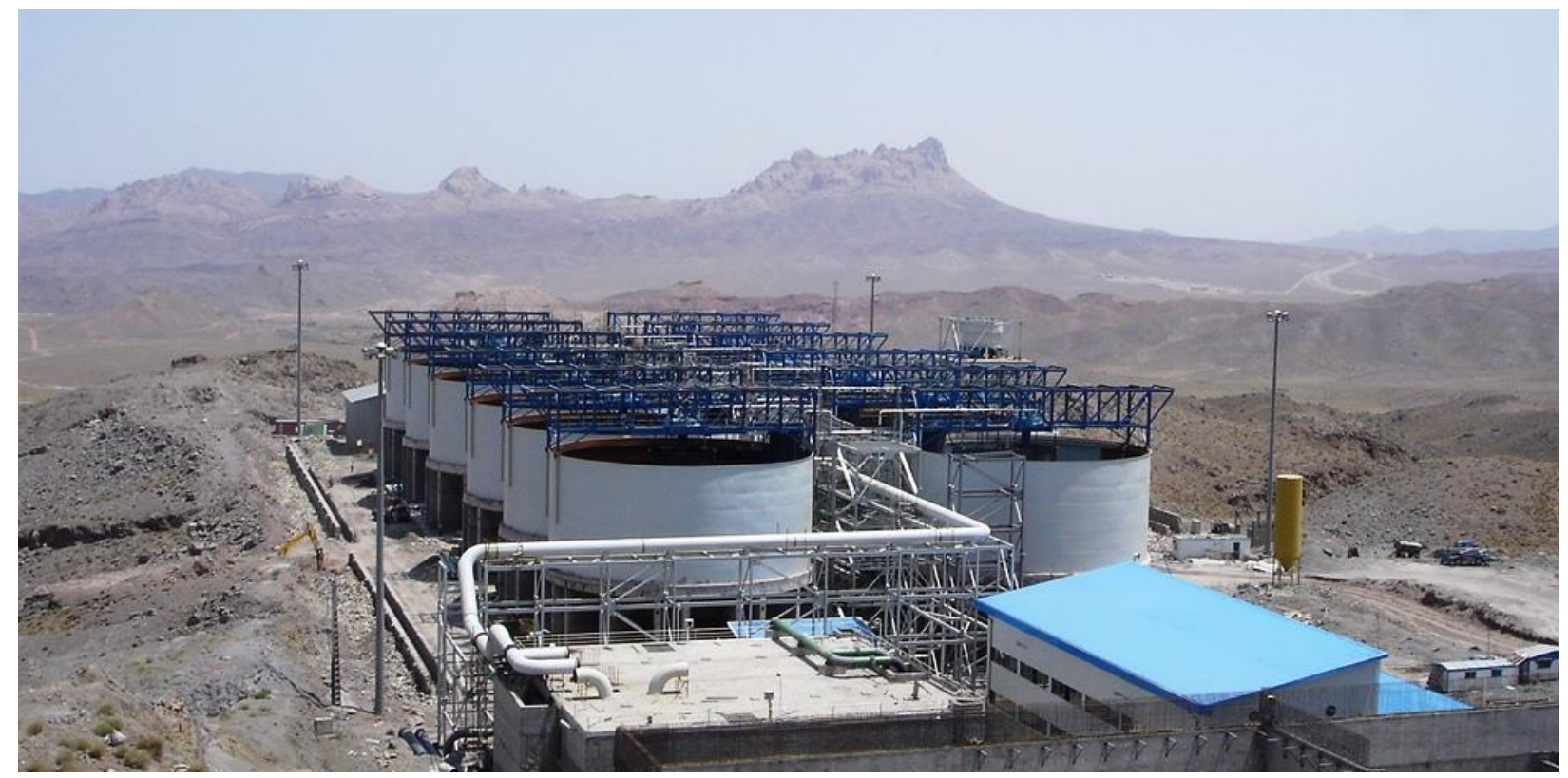

\section{Figure 5 Paste thickener plant under construction}

The design underflow density is $60 \%$ solids, a lower figure than might be expected but a reflection of the clayey fines component in the tailings, and a deliberate degree of conservatism in the design.

The paste thickener plant, as can be seen from Figure 1, is located between the concentrator site and the tailings dam (main embankment). The initial thickening takes place at the concentrator in conventional and high-rate thickeners, and delivers an underflow tailings stream with a solids concentration of approximately $42 \%$ solids. Previously, this was discharged down an open flume to the storage. For the upgrade, an off-take structure on the existing flume diverts the tailings stream into a $1 \mathrm{~m}$ diameter gravity pipeline to the paste thickener plant at an elevation of 2,400 m.

The paste thickeners were commissioned in 2013 , and the design underflow density of $60 \%$ has been achieved from time to time but not yet consistently. Main operational challenges comprise fluctuation in the flow and properties of the input tailings, uneven distribution of flow into the thickeners, control of discharge, measurements and automation. The underflow solids concentration from the paste thickeners during the period of March to May 2014 is plotted in Figure 6.

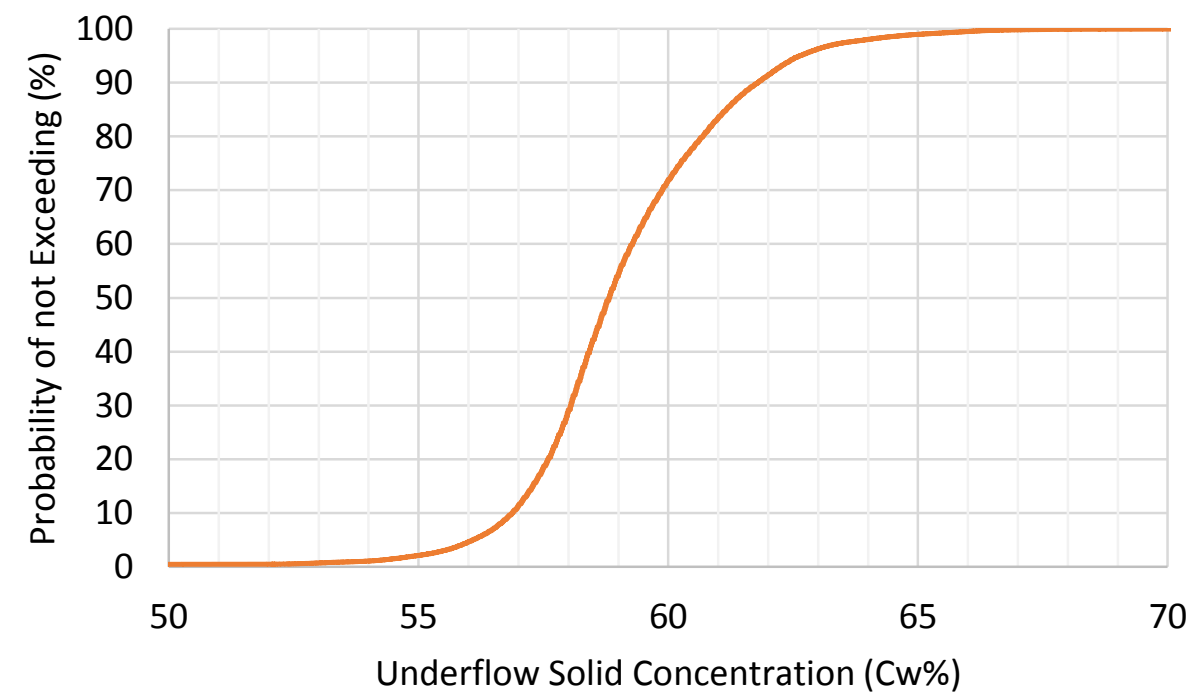

Figure 6 Paste thickener underflow solids concentration (between March and May 2014) 
Figure 6 suggests that the underflow solid concentration during the studied period is mostly between $58 \%$ and $61 \%$. Also, during a site visit by ATCW and FLS representatives in December 2013, the Marcy Gauge measurement of the underflow solid concentration showed an average of $60.5 \%$ on the date of the visit.

\section{Beach slope evaluation}

The thickener underflow discharge is split into two arms of the impoundment: the Shur River arm to the west, and the Gowd-e-Ahmar arm to the east. There is no requirement for underflow pumping to the storage at any stage of the development. Water recovery is by pontoon-mounted pumps at the north-west corner of the impoundment. Design beach slopes are presented in Table 1.

Table 1 Adopted beach slopes

\begin{tabular}{ccccc}
\hline & Top & Middle & Bottom & Runout \\
\hline $\begin{array}{c}\text { 33 Mtpa into Shur River and } \\
\text { Gowd-e-Ahmar 50:50 split) }\end{array}$ & $1.75 \%$ & $1.35 \%$ & $0.95 \%$ & $0.50 \%$ \\
\hline
\end{tabular}

The beach slope is assumed to be concaved in shape (Seddon \& Fitton 2011). As seen in Table 1, concavity in the beach profile has been included in the design to reflect expected variations in thickener performance within a range below the nominal maximum design value.

Whilst the forecast beach slopes are moderate, it must be appreciated that the distance from final head-ofbeach to the recovery pond is of the order of $10 \mathrm{~km}$. The overall height difference between head-of-beach and toe will be around $100 \mathrm{~m}$. The final embankment raise is only $40 \mathrm{~m}$, to store almost $900 \mathrm{Mt}$ of additional tailings. The height would have been much greater, indeed to a quite impractical height for the site topography, without the 'stacking' of tailings through down-valley discharge. The expected tailings beach configuration following deposition of the additional $900 \mathrm{Mt}$ is shown in Figure 7.

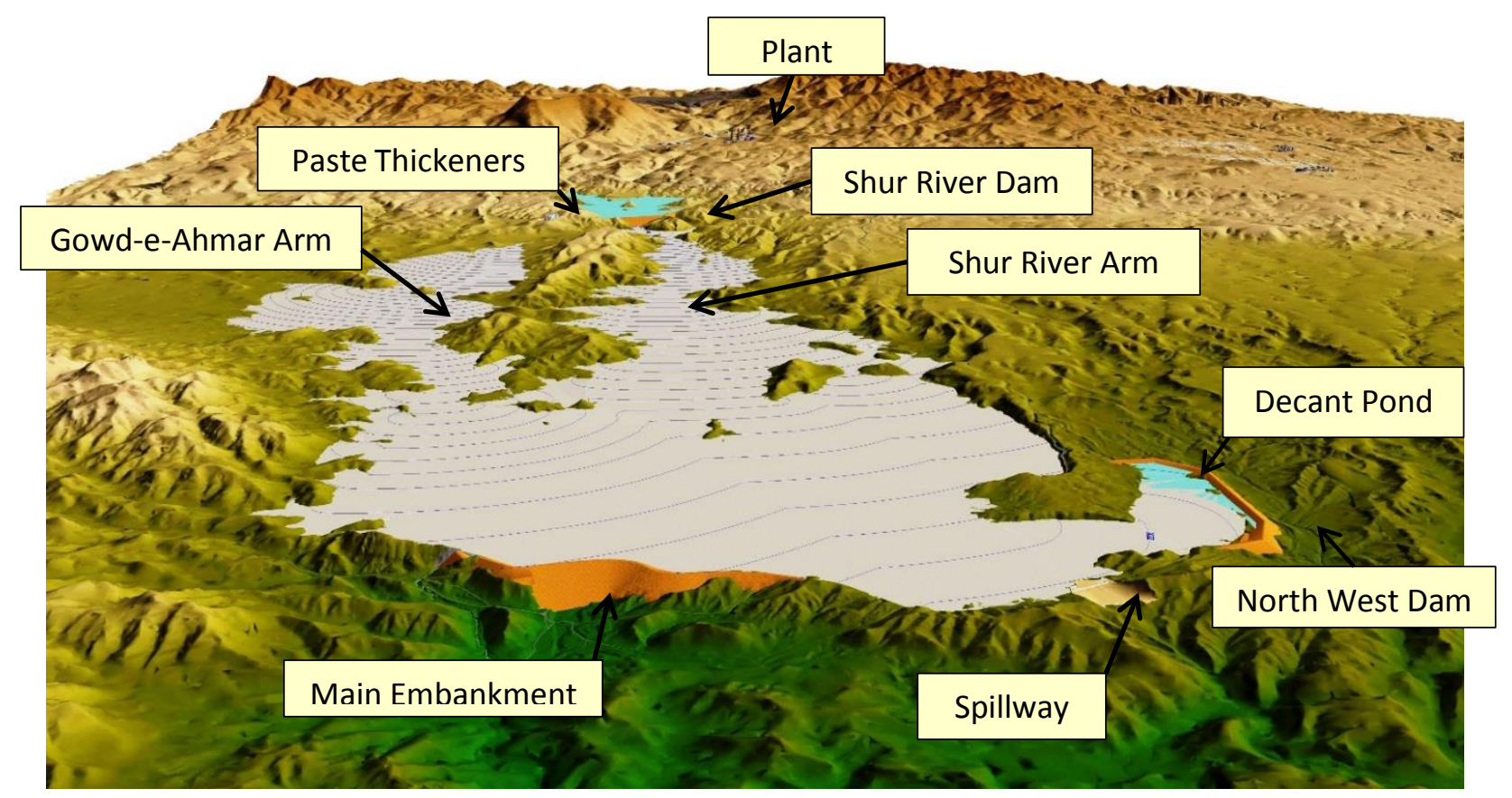

Figure 7 Expected final beach layout

A combination of shortage of suitable low permeability material for construction, plus considerations of seismic stability in this highly seismic environment, presented some challenges for the designers (Noske 2010). A zoned rockfill embankment with a PVC geo-membrane composite on the upstream face was selected to address these issues (Scuero \& Vaschetti 2009). 
The overall height of the main embankment after the final raise will be $110 \mathrm{~m}$, with a crest elevation sloping from elevation of 2,216 $\mathrm{m}$ at the eastern end to 2,212.5 $\mathrm{m}$ at the west. An emergency spillway will be constructed with a crest elevation of 2,189 $\mathrm{m}$.

Early beach slope surveys are encouraging, but it is too soon for the establishment of a large-scale mature beach profile at the time of writing. An early indication of the achieved beach slope is seen in Figure 8 , taken soon after the completion of commissioning. The initial measured slope after the commissioning of the paste thickeners is between 1.4 to $2 \%$. Whilst not yet fully in accordance with design, this is considered to be reasonable at this stage, as further improvement in underflow density and beach slope are expected.

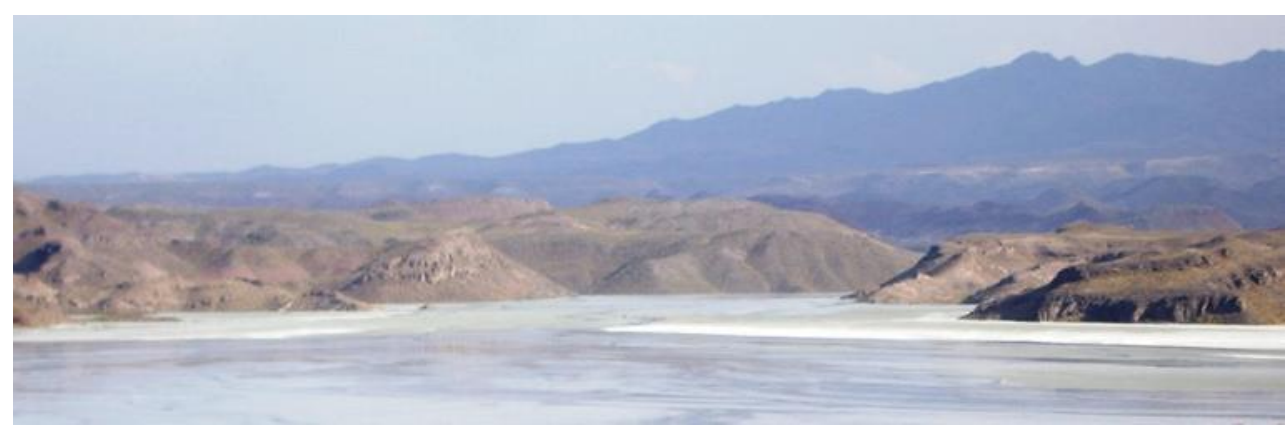

Figure 8 Early indication of achieved beach slope after commissioning of the paste thickeners (view upstream in Gowd-e-Ahmar arm)

\section{$6 \quad$ Fresh water supply}

Make-up water supply comes from an alluvial borefield over $30 \mathrm{~km}$ from the mine (the Khatoon-Abad borefield). Water recovery and management practices at the tailings dam, which had been acceptable at the early, low mine throughputs, were clearly inadequate for the expansions and the mine was now also competing for water with increased local demand from agriculture consumers. This was leading to depletion of the aquifer at an unsustainable rate.

By utilising the paste thickeners, two main advantages with respect to water conservation have been achieved. Firstly, all of the water content between partially thickened tailings (at $42 \%$ solids) and paste ( $60 \%$ solids) is no longer exposed to loss by evaporation from the deposited tailings. This reduction in evaporation represents an approximate $25 \%$ saving in water.

Secondly, testing indicates that the initial settled dry density should increase from $0.96 \mathrm{t} / \mathrm{m}^{3}$ for tailings at $42 \%$ solids concentration to $1.03 \mathrm{t} / \mathrm{m}^{3}$ for tailings with $60 \%$ solids concentration. Initial settled density controls the amount of water that is trapped in the tailings solids at the point of initial deposition in the tailings storage facility and hence is related to the final retained water in the tailings. This increase represents an approximate $10 \%$ saving in retained water.

As the result of the implementation of this plan, the make-up water demand decreased from around $0.46 \mathrm{~m}^{3} / \mathrm{t}$ before implementation of the system to approximately $0.25 \mathrm{~m}^{3} / \mathrm{t}$.

Figure 9 illustrates a simplified diagram of water transportation within the system. 


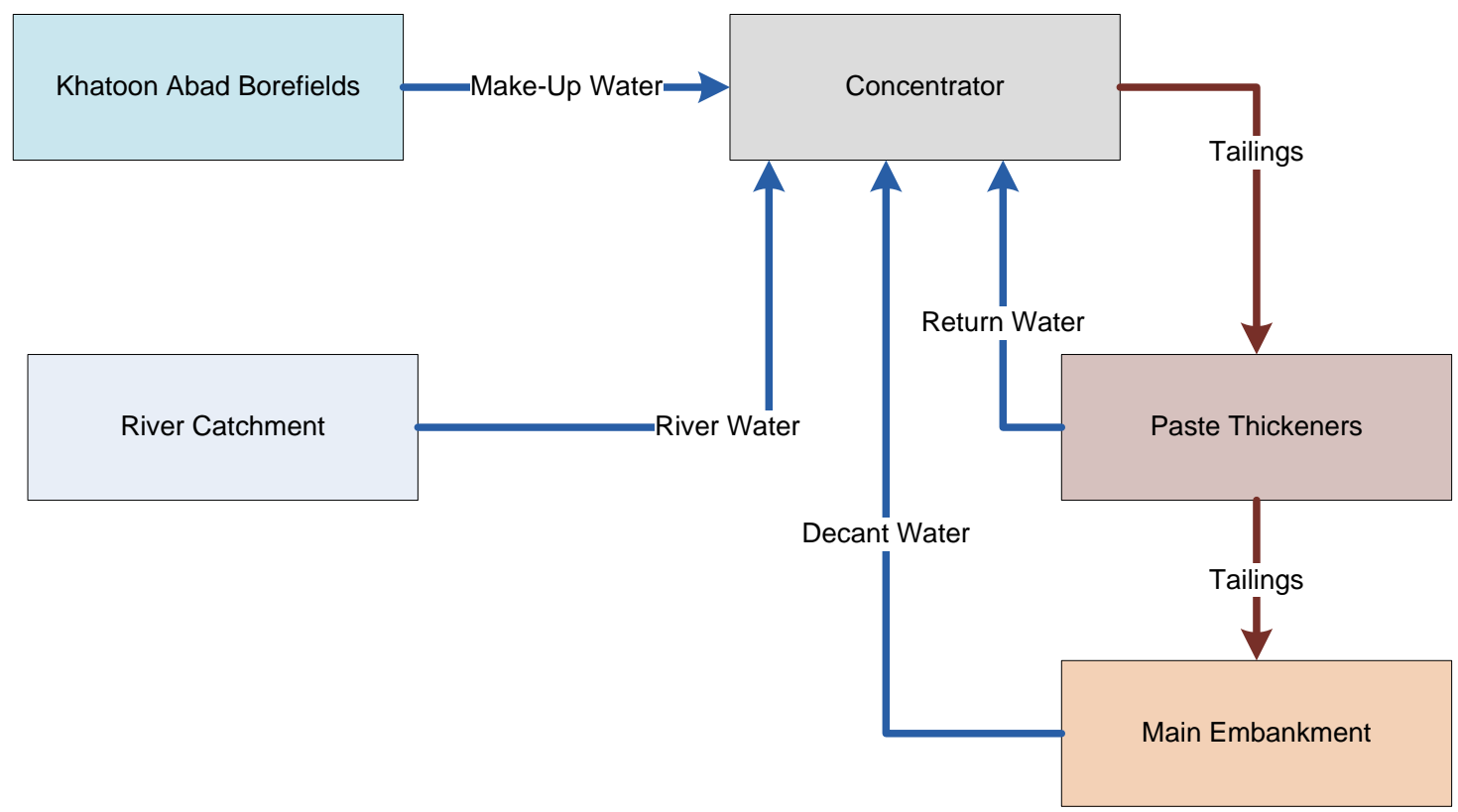

Figure 9 A simplified water flow diagram at Sarcheshmeh

The main water sources into the concentrator at Sarcheshmeh mine are presented in Figure 10. Over 50\% of the concentrator water is supplied from the return water and the fresh water portion is relatively low. Also it is seen that the decant water (bleed from paste tailings after deposition) supplies a very small part of the required water at the concentrator.

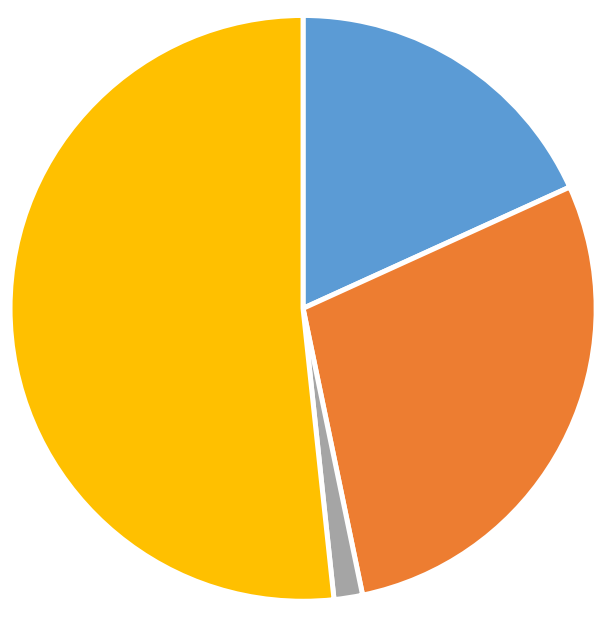

घake-Up Water $\quad$ River Water $\backsim$ Decant Water $\backsim$ Return Water (Thickeners overflow)

Figure 10 Main water sources into the concentrator at Sarcheshmeh plant

\section{$7 \quad$ Results and discussions}

Prior to utilisation of the paste thickeners and the discharge of paste thickened tailings, the achieved beach slope was measured at approximately $0.25 \%$. This was at $42 \%$ solids concentration with total throughput of $23 \mathrm{Mtpa}$. By utilising paste thickeners and the proposed design, the following have been achieved:

- Measured beach slopes between 1.4 to $2.0 \%$ at the head of the beach flattening to $0.5 \%$ at the bottom. This results in a significant reduction in the height of the embankment at the main embankment location. Also, further improvement in the thickeners underflow characteristics is 
expected which will result in further saving in the embankment construction in the life of the mine.

- The performance of the thickeners, as illustrated in Figure 6, explains the concave shape of the beach profile and also confirms that the design profile used by ATC Williams (Table 1) is a reasonable approach.

- Although more improvement is expected, the early operation results are satisfactory and demonstrate a successful utilisation of thickened tailings.

- Less evaporation loss and higher initial settled dry density. This will result in a significant increase in water recovery and hence less requirement for fresh water make-up from the Khatoon Abad borefields.

This project shows that the adoption of thickened tailings disposal in large-scale mining operations provides practical disposal measures that deliver significant cost saving and water conservation advantages.

\section{Acknowledgement}

The authors wish to express their gratitude to Mr Khoshniaz and Mr Seif, successive heads of the Integrated Water Master Plan at NICICO at various stages of the project, for their support and cooperation. Also, the managers and engineers at both ATC Williams and Middle East Water and Environment should be acknowledged for their technical support.

\section{References}

MacNamara, L, Khoshniaz, N \& Hashemi, S 2011, 'The Sar Cheshmeh thickened tailings disposal project', in RJ Jewell \& AB Fourie (eds), Proceedings of the 14th International Seminar on Paste and Thickened Tailings, Australian Centre for Geomechanics, Perth, pp. 237-244.

Noske, C 2010, 'Geocomposite faced rockfill - an innovative means of water-proofing tailings storages', in AB Fourie \& RJ Jewell (eds), Proceedings of the First International Seminar on the Reduction of Risk in the Management of Tailings and Mine Waste, Australian Centre for Geomechanics, Perth, pp. 283-296.

Scuero, AM \& Vaschetti, GL 2009, 'Unconventional design in dam raising: Sar Cheshmeh tailings dam', ICOLD 23rd Congress, International Commission on Large Dams, Paris.

Seddon, KD \& Fitton, T 2011, 'Realistic beach slope prediction and design', in R Jewell \& A Fourie (eds), Proceedings of the 14 ${ }^{\text {th }}$ International Seminar on Paste and Thickened Tailings, Australian Centre for Geomechanics, Perth, pp. 281-294.

Williams, P 2000, 'Evolution of thickened tailings disposal in Australia', Paste Technology 2000, Australian Centre for Geomechanics, Perth, Australia. 
